\title{
Penentuan Pemilihan Komputer Untuk game online Pada Jasa Penyedia Warnet dengan Metode Multi-Factor Evaluation Process
}

\author{
Waris Pardingatan Sinaga*, Agus Perdana Windarto, Irfan Sudahri Damanik \\ Program studi Sistem Informasi, STIKOM Tunas Bangsa, Pematangsiantar, Indonesia \\ Email: ${ }^{1, *}$ warispardingatansinaga@ @mail.com, ${ }^{2}$ agus.perdana@ amiktunasbangsa.ac.id, ${ }^{3}$ irfansudahridamanik@ amiktunasbangsa.com \\ Email Penulis Korespondensi: warispardingatansinaga@gmail.com

\begin{abstract}
Abstrak-Penelitian ini bertujuan untuk membantu pihak penyedia jasa warnet dalam memilih komputer gaming yang sesuai dengan faktor kebutuhan. Metode yang digunakan adalah Sistem Pendukung Keputusan dengan menggunakan Multi-Factor Evaluation Process (MFEP). Data diperoleh dengan cara observasi dan wawancara pada jasa penyedia warnet di kota pematangsiantar. Kriteria yang digunakan 7 kriteria: Prosesor (X1), Motherboard (X2), RAM (X3), VGA card (X4), Storage (X5), Casing (X6), Power Supply (X7) dan 5 alternatif: Asus (A1), Acer (A2), Lenovo (A3), Dell (A4) dan Toshiba (A5). Hasil dari penelitian menunjukkan bahwa alternatif toshiba (A5) menjadi rekomendasi pertama dengan nilai akhir 3.95. Alternatif Asus (A1) menjadi rekomendasi kedua dengan nilai akhir 3.75 dan Lenovo (A3) menjadi rekomendasi ketiga dengan nilai akhir 3.4.
\end{abstract}

Kata Kunci: SPK; Metode MFEP; Jasa Warnet; Perangkingan; Gaming

Abstract-This study aims to help internet cafe service providers in choosing gaming computers that are in accordance with the needs factor. The method used is the Decision Support System using the Multi-Factor Evaluation Process (MFEP). Data is obtained by observing and interviewing the services of internet cafe providers in pematangsiantar city. The criteria used are 7 criteria: Processor (X1), Motherboard (X2), RAM (X3), VGA card (X4), Storage (X5), Casing (X6), Power Supply (X7) and 5 alternatives: Asus (A1), Acer (A2), Lenovo (A3), Dell (A4) and Toshiba (A5). The results of the study indicate that the Toshiba alternative (A5) is the first recommendation with a final value of 3.95. Alternative Asus (A1) becomes the second recommendation with the final value 3.75 and Lenovo (A3) being the third recommendation with the final value 3.4 .

Keywords: DSS; MFEP Method; Internet Cafe Service; Ranking; Gaming

\section{PENDAHULUAN}

Perkembangan teknologi yang melangkah menuju Revolusi 4.0, membuat tuntutan kehidupan yang dirasakan semakin Berat dan bermacam. Hal tersebut menjadikan siklus stress yang cukup tinggi pada kehidupan masyarakat di berbagai wilayah. Untuk merenggangkan stress tersebut, kita membutuhkan waktu rehat atau Hiburan. Bermain games menjadi pilihan kebanyakan masyarakat untuk mengatasi tingkat stress dari beratnya tanggungan kehidupan. Seiring maju nya IPTEK pada era trendi ini membuat banyak pilihan macam jenis games. Tidak hanya untuk Hiburan namun aplikasi games telah menjadi Peluang industri yang sangat menonjol. Games yang lampau selalu dikaitkan dengan masa kanakkanak ternyata telah menyeruput perhatian remaja dan bahkan kalangan orang dewasa. Games di era perkembangan teknologi Revolusi 4.0 melibatkan yang namanya internet. Internet saat ini bukan hanya sekedar kebutuhan, tetapi juga telah menjadi life style. Games yang menjelma menjadi kebutuhan bagi semua lapisan kalangan dan sebagai salah satu cara menghindari stress. Tidak semua orang dapat menikmati permainan games mengingat mahalnya biaya koneksi internet, hardware computer canggih serta persebaran jaringan internet yang tidak merata. Menyelesaikan hambatan tersebut maka hadirlah bisnis penyedia jasa internet atau biasa disebut dengan istilah warung internet (Warnet). Warnet memberikan keuntungan yang cukup besar bagi pengguna khususnya lapisan masyarakat yang ingin bermain games. Pengguna tidak perlu membeli komputer dan tidak perlu berlangganan jasa Internet, hanya membayar biaya sewa pemakaian saja dan sudah bisa mengakses Internet dengan kecepatan tinggi. Seiring perkembangan zaman, penyedia jasa warnet selalu meningkatkan kualitas pelayanan kepada pengguna. Tidak sedikit penyedia jasa warnet menginvestasikan dana yang besar untuk membeli kebutuhan warnet seperti hardware komputer dan komputer itu sendiri agar pengguna merasa nyaman saat menggunakan jasa warnet tersebut. Dari hasil observasi, para penyedia jasa warnet sering kali mengabaikan kualitas dan spesifikasi komputer yang mereka sediakan. Komputer yang mencukupi untuk game khususnya yang bersifat online tidak harus spek mahal, tetapi dengan spesifikasi komputer berharga ekonomis, dan dengan pemilihan komponen komputer yang tepat, pengguna dapat bermain game online dengan lancar. Penelitian ini dibuat untuk melakukan pengujian komputer yang ideal untuk game online bagi penyedia jasa warnet dengan menggunakansistem pendukung keputusan.

Pengambilan keputusan untuk menentukan pemilihan perangkat komputer yang ideal untuk game online pada jasa penyedia warnet bukan untuk mengantikan kedudukan seorang pengambil keputusan tetapi memberi dukungan berupa informasi sehingga membantu seorang pengambil keputusan dalam mengambil keputusan untuk suatu permasalahan.Permasalahan pengambilan keputusan yang dibahas disini adalah sistem pendukung keputusan multikriteria dengan metode Multi-Factor Evaluation Process (MFEP). Metode MFEP dapat mengasung pertimbangan subyektif dan intuitif tentang faktor yang dianggap perlu. Pertimbangan - pertimbangan tersebut berupa pembagian bobot (weighting system) atas multifactor yang terlibat dan dianggap perlu. Beberapa penelitian yang lampau telah dilakukan untuk menyelesaikan permasalahan dengan menggunakan metode Multi-Factor Evaluation Process (MFEP). Salah satunya adalah [1]. Studi menjelaskan bahwa Sistem Pendukung Keputusan sebagai 
alternatif sampel pemilihan tanaman pangan yang ada di Kabupaten Musi Rawas dengan menggunakan metode Multi Factor Evaluation Process.

Beberapa sampel yang menjadi penilaian adalah karakteristik lahan, lingkungan, tadah hujan dan pembibitan. Perolehan dari studi ini berupa perangkingan yang kedepan nya akan menjadi tolak ukur dalam pengambilan keputusan terkait pemilihan tanaman pangan yang cocok di Kabupaten Musi Rawas. Diharapkan pelaksanaan penelitian dapat membangun sebuah sistem pendukung keputusan dengan metode Multi-Factor Evaluation Process (MFEP) pada pemilihan komputer untuk game online pada jasa penyedia warnet di kota pematangsiantar sehingga mempermudah para pengambil keputusan khususnya penyedia jasa warnet dalam memilih komputer untuk game online yang sesuai dengan faktor kebutuhan serta menambah pengetahuan penulis dalam bidang sistem pendukung keputusan khususnya tentang Multi-Factor Evaluation Process (MFEP).

\section{METODOLOGI PENELITIAN}

Dalam hal ini perlu dilakukan tahapan atau gambaran yang dilakukan dalam melakukan penelitian yang dinamakan dengan kerangka penelitian, di butuhkan kerangka penelitian untuk memudahkan peneliti dalam melakukan penelitian. Berikut adalah gambar tahapan-tahapan penelitian yang dilakukan oleh penulis:

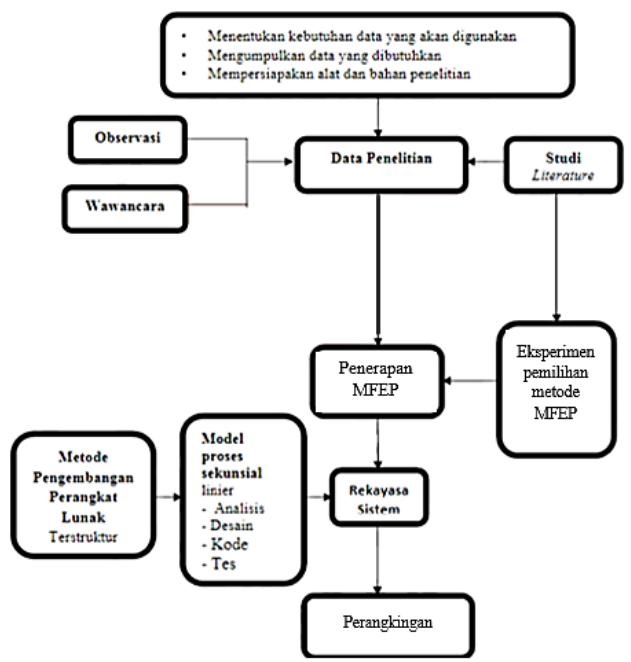

Penjelasan dari Gambar 1 adalah

Gambar 1. Kerangka Penelitian

a) Menentukan kebutuhan data yang digunakan.

Data yang dimaksud adalah Pengumpulan data yang dilakukan melalui observasi, angket/kuisioner dan wawancara pada penyedia jasa warnet di kota Pematangsiantar.

b) Mengumpulkan data yang dibutuhkan.

Setelah menentukan data apa saja yang dibutuhkan dalam penelitian ini kemudian data dikumpulkan untuk diproses.

c) Mempersiapkan alat dan bahan penelitian.

Yang dimaksud alat bahan disini adalah yang digunakan untuk membuat aplikasi perangkingan dengan menggunakan metode MFEP.

d) Studi Literatur.

Mengumpulkan informasi dan mempelajari materi serta sumber-sumber data yang berhubungan dengan SPK dalam pengimplementasian metode MFEP kedalam suatu program, teknologi internet, maupun materi atau sumber-sumber lain yang terkait dengan penelitian ini.

e) Analisa Sistem (Penerapan Metode MFEP).

Menganalisa sistem pendukung keputusan yang telah dikumpulkan sebelumnya melalui studi literatur.

f) Implementasi Sistem (Rekayasa Sistem).

Pada tahap ini dilakukan pembuatan sistem sesuai dengan analisis dan perancangan dengan menggunakan aplikasi web dan database $M y S Q L$.

g) Pengujian Sistem.

Pada tahap ini dilakukan pengujian sistem, apakah implementasi telah selesai.

Dalam dunia game pada Personal Computer (PC), membangun PC yang ekonomis dan berkualitas yang sesuai dengan kondisi penyedia jasa warnet. Oleh karena itu dalam hasil wawancara dengan jasa penyedia warnet yang ada dikota pematangsiantar, bahwa kategori game pada Personal Computer (PC) berdasarkan tiga tingkatan dilihat dari segi ekonomisnya yaitu low-end, mid-end and high-end. Peneliti menggunakan spesifikasi komputer low-end mengingat spesifikasi ini diperuntukkan yang masih sekolah atau kuliah. Pada penelitian ini digunakan 7 atribut dalam melakukan penilaian terhadap pemilihan komputer gaming pada jasa penyedia warnet. Atribut yang digunakan adalah sebagai berikut: 


\section{TIN: Terapan Informatika Nusantara}

Vol 2, No 8, Januari 2022, Hal 513-520

ISSN 2722-7987 (Media Online)

Website https://ejurnal.seminar-id.com/index.php/tin

DOI 10.47065/tin.v2i8.1246

a) Motherboard (X1).

b) Prosesor (X2).

c) VGA Card (X3).

d) RAM (X4).

e) Storage (X5).

f) Power Supply (X6).

g) Casing (X7).

Algoritma yang digunakan dalam penelitian ini adalah salah satu bagian dari algoritma Sistem Pendukung Keputusan (SPK) yaitu metode MFEP (Multifactor Evaluation Process). Gambar flowchart metode MFEP (Multifactor Evaluation Process) dapat dilihat pada Gambar 2.

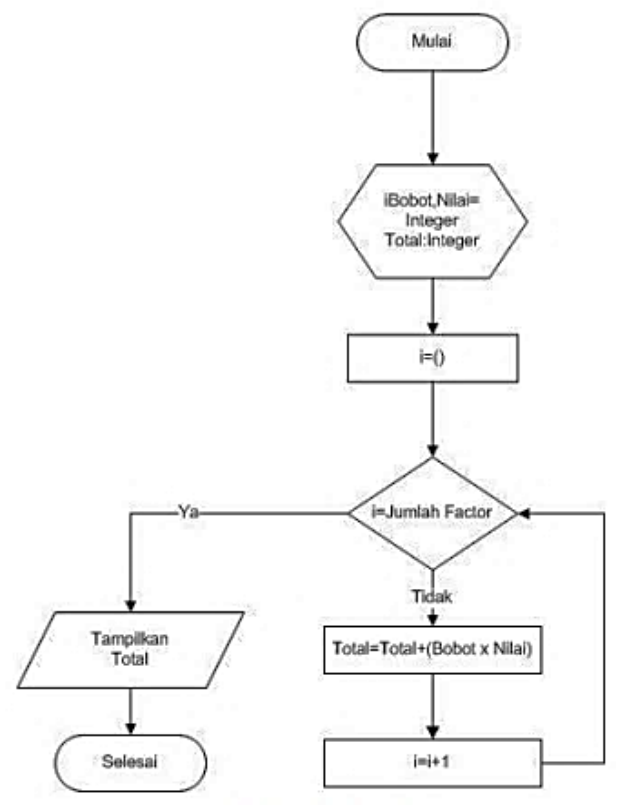

Gambar 2. Flowchart MFEP (Multifactor Evaluation Process)

\section{HASIL DAN PEMBAHASAN}

Dalam hal ini melakukan perhitungan dengan menggunakan metode MFEP harus berdasarkan data penelitian yang dilakukan. Dalam hal ini peneliti menggunakan teknik pengumpulan data dengan wawancara dan observasi kepada jasa penyedia warnet dikota pematangsiantar. Data kriteria penelitian yang didapatkan dari hasil observasi dapat dilihat pada Tabel 1 di bawah ini :

Tabel 1. Kriteria Penilaian

\begin{tabular}{lll}
\hline No & Inisial & Kriteria \\
\hline 1 & X1 & Prosesor \\
2 & X2 & Motherboard \\
3 & X3 & RAM \\
4 & X4 & VGA \\
5 & X5 & Storage \\
6 & X6 & Casing \\
7 & X7 & Power Supply \\
\hline
\end{tabular}

Berdasarkan tabel 1dapat dijelaskan bahwa kriteria yang digunakan memiliki pembobotan yang berbeda. Hasil pembobotan dikonversi kebilangan persen dimana sebelumnya pembobotan setiap kriteria menggunakan standar linkert. Adapun kriteria pembobotan yang diperoleh dari hasil wawancara adalah:

1) Keriteria Prosesor lebih baik dibanding semua kritera yang ada

2) Kriteria VGA Card, RAM memiliki nilai yang sama dan lebih baik dari semua kriteria setelah kriteria Motherboard

3) Kritera Storage lebih baik dari semuanya setelah kriteria Motherboard, VGA Card dan RAM

4) Kriteria Motherboard lebih baik dari kriteria Power Supply, Casing

5) Kriteria Power Supply, Casing memiliki bobok nilai yang sama

Hasil pembobotan menggunakan standar linkert akan dikonversi menggunakan persen sehingga pembobotan kriteria dapat dilihat pada tabel 2 berikut: 


\section{TIN: Terapan Informatika Nusantara}

Vol 2, No 8, Januari 2022, Hal 513-520

ISSN 2722-7987 (Media Online)

Website https://ejurnal.seminar-id.com/index.php/tin

DOI 10.47065/tin.v2i8.1246

Tabel 2. Pembobotan Kriteria Penilaian

\begin{tabular}{llll}
\hline No & Inisial & \multicolumn{1}{c}{ Kriteria } & Bobot (\%) \\
\hline 1 & X1 & Prosesor & $25 \%$ \\
2 & X2 & Motherboard & $10 \%$ \\
3 & X3 & RAM & $20 \%$ \\
4 & X4 & VGA & $20 \%$ \\
5 & X5 & Storage & $15 \%$ \\
6 & X6 & Casing & $5 \%$ \\
7 & X7 & Power Supply & $5 \%$ \\
\hline
\end{tabular}

Setelah proses pembobotan kriteria ditentukan, selanjutnya menentukan Data alternatif penelitian yang didapatkan dari hasil observasi seperti pada Tabel 3 di bawah ini :

Tabel 3. Data Alternatif komputer gaming

\begin{tabular}{lll}
\hline No & Inisial & \multicolumn{1}{c}{ Alternatif } \\
\hline 1 & A1 & Asus \\
2 & A2 & Acer \\
3 & A3 & Lenovo \\
4 & A4 & Dell \\
5 & A5 & Toshiba \\
\hline
\end{tabular}

Pada tabel 3 dapat dijelaskan bahwa alternatif yang digunakan merupakan komputer gaming yang menjadi sasaran bagi penyedia jasa warnet. Dari 5 penyedia jasa warnet yang terkenal di kota pematangsiantar dapat diperoleh data mentah penelitian seperti yang ditunjukkan pada tabel 5 berikut:

Tabel 4. Data Mentah Penelitian

\begin{tabular}{|c|c|c|c|c|c|c|c|}
\hline Jenis PC & Prosesor & $\begin{array}{l}\text { Mother } \\
\text { Board }\end{array}$ & RAM & VGA & Storage & Casing & Power Supply \\
\hline Asus & $\begin{array}{l}\text { AMD Vishera } \\
\text { FX-4350 } \\
4.2 \mathrm{Ghz} \text { Cache } 4 \\
\text { MB }\end{array}$ & $\begin{array}{l}\text { ASUS } \\
\text { M5A78L-M } \\
\text { LE/USB3 }\end{array}$ & $\begin{array}{lr}\text { Team Elite Plus } \\
\text { DDR } 3 \quad \text { PC } \\
12800 \quad \text { Dual } \\
\text { Channel } 8 \text { GB }\end{array}$ & $\begin{array}{ll}\text { XFX } & \\
\text { Radeon } & \text { R7 } \\
360 \quad 2 & \text { GB } \\
\text { DDR5 } & \end{array}$ & 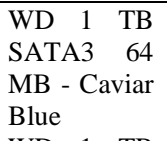 & $\begin{array}{l}\text { Thermalta } \\
\text { ke Versa } \\
\text { N21 }\end{array}$ & $\begin{array}{l}\text { Super Flower } \\
\text { BRONZE FX } \\
550 \text { W } 80+ \\
\text { Bronze }\end{array}$ \\
\hline Acer & $\begin{array}{l}\text { Intel Core i3- } \\
2130 \quad 3.4 \mathrm{Ghz} \\
\text { Cache } 3 \mathrm{MB}\end{array}$ & $\begin{array}{l}\text { ASRock } \\
\text { H61M-VG4 }\end{array}$ & $\begin{array}{l}\text { Corsair DDR3 } \\
\text { Vengeance } \\
\text { Black PC12800 } \\
4 \text { GB (2X2 GB) }\end{array}$ & $\begin{array}{l}\text { MSI } \\
\text { Radeon R7- } \\
2402 \text { GB }\end{array}$ & 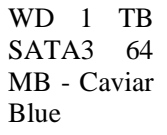 & $\begin{array}{l}\text { Cooler } \\
\text { Master } \\
\text { CMP102C }\end{array}$ & $\begin{array}{l}\text { Antec } \quad \text { VP } \\
\text { Series } 500 \mathrm{~W}\end{array}$ \\
\hline Lenovo & $\begin{array}{lr}\text { AMD } & \text { Kaveri } \\
\text { A8-7600 } & \\
3.1 \mathrm{GHz} & \\
\text { (Radeon } & \text { R7 } \\
\text { series) } & \end{array}$ & $\begin{array}{l}\text { ASRock } \\
\text { FM2A68M- } \\
\text { DG3+ }\end{array}$ & $\begin{array}{l}\text { Team Elite Plus } \\
\text { DDR3 PC12800 } \\
\text { 1600Mhz Dual } \\
\text { Channel } 4 \text { GB } \\
(2 X 2 \text { GB) }\end{array}$ & 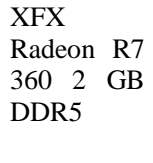 & $\begin{array}{lr}\text { WD } & 1 \\
\text { SATA3 } & \text { TB } \\
\text { MB } & \text { - Caviar } \\
\text { Blue }\end{array}$ & $\begin{array}{l}\text { Cooler } \\
\text { Master } \\
\text { CMP 102C }\end{array}$ & $\begin{array}{l}\text { Antec } \quad \text { VP } \\
\text { Series } 500 \mathrm{~W}\end{array}$ \\
\hline Toshiba & $\begin{array}{l}\text { Intel Core i3- } \\
6100\end{array}$ & $\begin{array}{l}\text { Gigabyte GA- } \\
\text { H110M-DS2 }\end{array}$ & $\begin{array}{lr}\text { Patriot } & \text { DDR3 } \\
\text { Viper } 3 & \text { Series } \\
\text { Dual Channel } \\
\text { PC19000 } 8 \mathrm{~GB} \\
\text { CL11 }\end{array}$ & $\begin{array}{lr}\text { Inno } & 3 \mathrm{D} \\
\text { GTX } & 9502 \\
\text { GB } & \text { OC } \\
\text { Series } & \end{array}$ & $\begin{array}{lr}\text { WD } & 1 \\
\text { SATA3 } & \text { TB } \\
\text { MB } & \text { - Caviar } \\
\text { Blue }\end{array}$ & $\begin{array}{l}\text { Thermalta } \\
\text { ke Versa } \\
\text { N21 }\end{array}$ & $\begin{array}{l}\text { Super Flower } \\
\text { BRONZE FX } \\
550 \text { W } 80+ \\
\text { Bronze }\end{array}$ \\
\hline
\end{tabular}

Untuk melakukan perhitungan dengan metode MFEP, setiap kriteria terdiri dari beberapa sub kriteria dimana proses ini nantinya menjadi penentu dalam proses perangkingan dengan menggunakan metode MFEP. Berikut ini adalah parameter nilai dan proses pengelompokan kriteria penilaian yang digunakan pada pemilihan komputer gaming pada jasa penyedia warnet.

Tabel 5. Parameter Penilaian

\begin{tabular}{ll}
\hline Parameter & Ukuran Nilai \\
\hline Sangat Bagus & 5 \\
Bagus & 4 \\
Cukup Bagus & 3 \\
Kurang Bagus & 2 \\
\hline
\end{tabular}




\section{TIN: Terapan Informatika Nusantara}

Vol 2, No 8, Januari 2022, Hal 513-520

ISSN 2722-7987 (Media Online)

Website https://ejurnal.seminar-id.com/index.php/tin

DOI 10.47065/tin.v2i8.1246

Tabel 6. Penilaian Sub Kriteria X1

\begin{tabular}{lll}
\hline Motherboard $(\mathrm{X1})$ & Kisaran & Nilai \\
\hline Msi Z170A Pro & Rp1.925.000 & Sangat Bagus \\
Gigabyte GA-H97M-D3H & Rp1.465.000 & Sangat Bagus \\
Asrock 970 Pro 3 & Rp1.100.000 & Sangat Bagus \\
Gigabyte GA-H110M-DS2 & Rp975.000 & Bagus \\
Asus M5A78L-M LE/USB3 & Rp840.000 & Bagus \\
Asrock H61M-VG4 & Rp785.000 & Cukup Bagus \\
Asrock FM2A68M-DG3+ & Rp700.000 & Kurang Bagus \\
\hline
\end{tabular}

Tabel 7. Penilaian Sub Kriteria X2

\begin{tabular}{lll}
\hline Prosesor $(\mathrm{X} 2)$ & Kisaran & Nilai \\
\hline Intel Core i5-6500 3,2Ghz - Cache 6 MB & $\mathrm{Rp} 2.855 .000$ & Sangat Bagus \\
Intel Core i5-4460 3,2Ghz & $\mathrm{Rp} 2.360 .000$ & Sangat Bagus \\
AMD Vishera FX-8320E 3.2Ghz & $\mathrm{Rp} 1.780 .000$ & Sangat Bagus \\
Intel Core i3-6100 & $\mathrm{Rp} 1.515 .000$ & Bagus \\
AMD Vishera FX 6300 3,5 Ghz & $\mathrm{Rp} 1.360 .000$ & Bagus \\
AMD Vishera FX-4350 4.2Ghz Cache 4 MB & $\mathrm{Rp} 1.219 .000$ & Cukup Bagus \\
AMD Kaveri A8-7600 3.1GHz (Radeon R7 series) & $\mathrm{Rp} 1.060 .000$ & Kurang Bagus \\
Intel Core i3-2130 3.4Ghz Cache 3 MB & Rp660.000 & Kurang Bagus \\
AMD Kaveri A6-7400K 3.5Ghz (Radeon R4 series) & Rp625.000 & Kurang Bagus \\
\hline
\end{tabular}

Tabel 8. Penilaian Sub Kriteria X3

\begin{tabular}{lll}
\hline VGA Card $(X 3)$ & Kisaran & Nilai \\
\hline Digital Alliance GeForce GTX 1060 6 GB DDR5 Jetstream & Rp4.080.000 & Sangat Bagus \\
Sapphire RX 480 4 GB DDR5 Nitro+ OC & Rp3.000.000 & Sangat Bagus \\
Digital Alliance GeForce GTX 1050 Ti 4 GB DDR5 StormX Series & Rp2.190.000 & Sangat Bagus \\
Inno 3D GTX 950 2 GB OC Series & Rp1.720.000 & Bagus \\
XFX Radeon R7 360 2 GB DDR5 & Rp1.425.000 & Bagus \\
PowerColor Radeon RX 460 2 GB Red Dragon & Rp1.380.000 & Cukup Bagus \\
MSI Radeon R7-240 2GB & Rp842.000 & Kurang Bagus \\
\hline
\end{tabular}

Tabel 9. Penilaian Sub Kriteria X4

\begin{tabular}{lll}
\hline$R A M(X 4)$ & Kisaran & Nilai \\
\hline Patriot DDR3 Viper 3 Series Dual Channel PC19000 8 GB CL11 & Rp731.000 & Sangat Bagus \\
Patriot DDR4 Viper 4 Xtreme Dual Channel PC19200 8 GB CL10 (2X4 GB) & Rp701.000 & Sangat Bagus \\
Team Elite Plus DDR 3 PC 12800 Dual Channel 8 GB & Rp672.000 & Sangat Bagus \\
Patriot DDR3 Viper 3 Series Dual Channel PC12800 8 GB CL9 & Rp630.000 & Bagus \\
Corsair DDR3 Vengeance Black PC12800 4 GB (2X2 GB) & Rp510.000 & Bagus \\
Team Elite Plus DDR3 PC12800 1600Mhz Dual Channel 4 GB (2X2 GB) & Rp418.000 & Cukup Bagus \\
Patriot DDR3 Signature Line Kit Series Dual Channel PC12800 4 GB & Rp335.000 & Kurang Bagus \\
\hline
\end{tabular}

Tabel 10. Penilaian Sub Kriteria X5

\begin{tabular}{lll}
\hline Storage $(X 5)$ & Kisaran & Nilai \\
\hline WD 1 TB SATA3 64 MB - Caviar Blue & Rp630.000 & Bagus \\
WDC 320 GB SATA2 8 MB & Rp245.000 & Cukup Bagus \\
\hline
\end{tabular}

Tabel 11. Penilaian Sub Kriteria X6

\begin{tabular}{lll}
\hline Power Supply (X6) & Kisaran & Nilai \\
\hline Super Flower Golden Green HX 550W - 80 Plus Bronze & Rp850.000 & Sangat Bagus \\
Super Flower BRONZE FX 550 W 80+ Bronze & Rp760.000 & Bagus \\
Antec VP Series 500 W & Rp585.000 & Cukup Bagus \\
\hline
\end{tabular}

Tabel 12. Penilaian Sub Kriteria X7

\begin{tabular}{lll}
\hline Casing $(\mathrm{X} 7)$ & Kisaran & Nilai \\
\hline Cooler Master HAF 912 COMBAT & Rp1.090.000 & Sangat Bagus \\
Thermaltake Versa N21 & Rp680.000 & Bagus \\
CoolerMaster CMP102C & Rp370.000 & Cukup Bagus \\
\hline
\end{tabular}

Sehingga diperoleh data konversi penelitian seperti yang ditunjukkan pada tabel berikut:

Tabel 13. Data Penelitian

\begin{tabular}{llllllllll}
\hline No & Jenis $P C$ & $\begin{array}{l}\text { Prosesor } \\
(X 1)\end{array}$ & $\begin{array}{l}\text { Motherboard } \\
(X 2)\end{array}$ & $\begin{array}{l}\text { RAM } \\
(X 3)\end{array}$ & $\begin{array}{l}\text { VGA } \\
(X 4)\end{array}$ & $\begin{array}{l}\text { Storage } \\
(X 5)\end{array}$ & $\begin{array}{l}\text { Casing } \\
(X 6)\end{array}$ & $\begin{array}{l}\text { Power } \\
(X 7)\end{array}$ & $\begin{array}{l}\text { Supply } \\
(X)\end{array}$ \\
\hline 1 & Asus & 3 & 4 & 4 & 4 & 4 & 4 & 4 \\
\hline
\end{tabular}


TIN: Terapan Informatika Nusantara

Vol 2, No 8, Januari 2022, Hal 513-520

ISSN 2722-7987 (Media Online)

Website https://ejurnal.seminar-id.com/index.php/tin

DOI 10.47065/tin.v2i8.1246

\begin{tabular}{|c|c|c|c|c|c|c|c|c|c|}
\hline No & Jenis $P C$ & $\begin{array}{l}\text { Prosesor } \\
(X 1)\end{array}$ & $\begin{array}{l}\text { Motherboard } \\
(X 2)\end{array}$ & $\begin{array}{l}R A M \\
(X 3)\end{array}$ & $\begin{array}{l}V G A \\
(X 4)\end{array}$ & $\begin{array}{l}\text { Storage } \\
(X 5)\end{array}$ & $\begin{array}{l}\text { Casing } \\
(X 6)\end{array}$ & $\begin{array}{l}\text { Power } \\
(X 7)\end{array}$ & Supply \\
\hline 2 & Acer & 2 & 3 & 4 & 2 & 4 & 3 & 3 & \\
\hline 3 & Lenovo & 2 & 2 & 5 & 4 & 4 & 3 & 3 & \\
\hline 4 & Dell & 2 & 2 & 2 & 3 & 3 & 3 & 3 & \\
\hline 5 & Toshiba & 4 & 3 & 5 & 4 & 3 & 4 & 4 & \\
\hline
\end{tabular}

\subsection{Penerapan Metode MFEP}

Langkah-langkah pemecahan menggunakan metode MFEP adalah sebagai berikut:

a) Dalam menentukan nilai bobot, penulis mencoba memasukan nilai sebagai sample perhitungan dimana bobot faktor total pembobotan harus sama dengan $1\left(\sum\right.$ pembobotan $\left.=1\right)$ atau disebut factor weight. Dapat dilihat pada Tabel di bawah ini

Tabel 14. Faktor dan Pembobotan

\begin{tabular}{lllll}
\hline No & Inisial & Kriteria & $\%$ Bobot & Pembobotan \\
\hline 1 & X1 & Prosesor & $25 \%$ & 0.25 \\
2 & X2 & Motherboard & $10 \%$ & 0.1 \\
3 & X3 & RAM & $20 \%$ & 0.2 \\
4 & X4 & VGA & $20 \%$ & 0.2 \\
5 & X5 & Storage & $15 \%$ & 0.15 \\
6 & X6 & Casing & $5 \%$ & 0.05 \\
7 & X7 & Power Supply & $5 \%$ & 0.05 \\
\multicolumn{7}{l}{ Total $\sum$} & & & 1 \\
\hline
\end{tabular}

b) Mengisikan Nilai bobot faktor sesuai dengan beberapa alternatif yang dijadikan sebagai kandiditat pemilihan komputer gaming. Nilai bobot faktor dan alternatif dapat dilihat pada Tabel di bawah ini:

Tabel 15. Nilai Faktor dan Alternatif

\begin{tabular}{lllllllll}
\hline No & PC & X1 & X2 & X3 & X4 & X5 & X6 & X7 \\
\hline 1 & Asus & 3 & 4 & 4 & 4 & 4 & 4 & 4 \\
2 & Acer & 2 & 3 & 4 & 2 & 4 & 3 & 3 \\
3 & Lenovo & 2 & 2 & 5 & 4 & 4 & 3 & 3 \\
4 & Dell & 2 & 2 & 2 & 3 & 3 & 3 & 3 \\
5 & Toshiba & 4 & 3 & 5 & 4 & 3 & 4 & 4 \\
\hline
\end{tabular}

c) Proses perhitungan weight evaluation merupakan perhitungan antara factor weight dan factor evaluation dengan penjumlahan, dari hasil weight evaluation dapat menentukan hasil evaluasi. Berikut adalah perhitungan weight evaluation pada beberapa alternatif

1) Weight Evaluaton Prosesor $\mathrm{W}_{\mathrm{E}}=\mathrm{F}_{\mathrm{E}} \times \mathrm{E}$

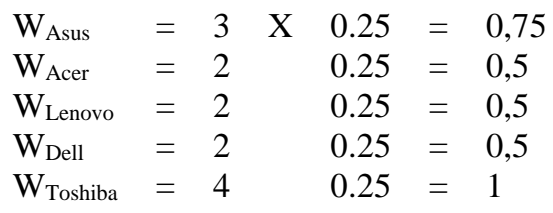

2) Weight Evaluaton Motherboard $\mathrm{W}_{\mathrm{E}}=\mathrm{F}_{\mathrm{E}} \times \mathrm{E}$

$\begin{array}{lllll}\mathrm{W}_{\text {Asus }} & =4 & \mathrm{X} & 0.1 & =0,4 \\ \mathrm{~W}_{\text {Acer }} & =3 & & 0.1 & =0,3 \\ \mathrm{~W}_{\text {Lenovo }} & =2 & & 0.1 & =0,2 \\ \mathrm{~W}_{\text {Dell }} & =2 & & 0.1 & =0,2 \\ \mathrm{~W}_{\text {Toshiba }}= & = & & 0.1 & =0,3\end{array}$

3) Weight Evaluaton RAM $\mathrm{W}_{\mathrm{E}}=\mathrm{F}_{\mathrm{E}} \times \mathrm{E}$

$\begin{array}{lllll}\mathrm{W}_{\text {Asus }} & =4 & \mathrm{X} & 0.2=0,8 \\ \mathrm{~W}_{\text {Acer }}=4 & & 0.2=0,8 \\ \mathrm{~W}_{\text {Lenovo }}=5 & & 0.2=1 \\ \mathrm{~W}_{\text {Dell }}= & = & 0.2 & =0,4 \\ \mathrm{~W}_{\text {Toshiba }}= & = & & 0.2=1\end{array}$

4) Weight Evaluaton VGA Card

$\begin{array}{llllll}\mathrm{W}_{\mathrm{E}}=\mathrm{F}_{\mathrm{E}} \times \mathrm{E} & & & & \\ \mathrm{W}_{\text {Asus }} & = & \mathrm{X} & 0.2 & = & 0,8 \\ \mathrm{~W}_{\text {Acer }} & = & & 0.2 & =0,4 \\ \mathrm{~W}_{\text {Lenovo }} & = & & & 0.2 & =0,8 \\ \mathrm{~W}_{\text {Dell }} & = & & 0.2 & =0,6 \\ \mathrm{~W}_{\text {Toshiba }} & = & & & 0.2 & =0,8\end{array}$

5) Weight Evaluaton Storage $\mathrm{W}_{\mathrm{E}}=\mathrm{F}_{\mathrm{E}} \times \mathrm{E}$

\begin{tabular}{|c|c|c|}
\hline $\mathrm{W}_{\text {Asus }}$ & $=$ & 4 \\
\hline $\mathrm{W}_{\text {Acer }}$ & $=$ & 4 \\
\hline $\mathrm{W}_{\text {Lenovo }}$ & $=$ & 4 \\
\hline $\mathrm{W}_{\text {Dell }}$ & $=$ & 3 \\
\hline $\mathrm{W}_{\text {Toshiba }}$ & $=$ & 3 \\
\hline
\end{tabular}

6) Weight Evaluaton Casing $\mathrm{W}_{\mathrm{E}}=\mathrm{F}_{\mathrm{E}} \times \mathrm{E}$

$\begin{array}{lllll}\mathrm{W}_{\text {Asus }} & =4 & \mathrm{X} & 0.05 & =0,2 \\ \mathrm{~W}_{\text {Acer }} & =3 & & 0.05 & =0,15 \\ \mathrm{~W}_{\text {Lenovo }} & =3 & & 0.05 & =0,15 \\ \mathrm{~W}_{\text {Dell }} & =3 & & 0.05 & =0,15 \\ \mathrm{~W}_{\text {Toshiba }} & =4 & 0.05 & =0,2\end{array}$




\section{TIN: Terapan Informatika Nusantara}

Vol 2, No 8, Januari 2022, Hal 513-520

ISSN 2722-7987 (Media Online)

Website https://ejurnal.seminar-id.com/index.php/tin

DOI 10.47065/tin.v2i8.1246

7) Weight Evaluaton Power Supply

$\mathrm{W}_{\mathrm{E}}=\mathrm{F}_{\mathrm{E}} \times \mathrm{E}$

$$
\begin{aligned}
& \mathrm{W}_{\text {Asus }}=4 \quad \mathrm{X} \quad 0.05=0,2 \\
& \mathrm{~W}_{\text {Acer }}=3 \quad 0.05=0,15
\end{aligned}
$$

$\begin{array}{llll}\mathrm{W}_{\text {Lenovo }}=3 & 0.05 & =0,15 \\ \mathrm{~W}_{\text {Dell }}=3 & 0.05 & =0,15 \\ \mathrm{~W}_{\text {Toshiba }}=4 & 0.05 & =0,2\end{array}$

Sehingga diperoleh hasil lengkap seperti yang ditunjukkan pada tabel berikut:

Tabel 16. Nilai Weight Evalauation

\begin{tabular}{lllllllll}
\hline No & PC & X1 & X2 & X3 & X4 & X5 & X6 & X7 \\
\hline 1 & Asus & 0,75 & 0,4 & 0,8 & 0,8 & 0,6 & 0,2 & 0,2 \\
2 & Acer & 0,5 & 0,3 & 0,8 & 0,4 & 0,6 & 0,15 & 0,15 \\
3 & Lenovo & 0,5 & 0,2 & 1 & 0,8 & 0,6 & 0,15 & 0,15 \\
4 & Dell & 0,5 & 0,2 & 0,4 & 0,6 & 0,45 & 0,15 & 0,15 \\
5 & Toshiba & 1 & 0,3 & 1 & 0,8 & 0,45 & 0,2 & 0,2 \\
\hline
\end{tabular}

d) Menjumlahkan seluruh hasil weight evaluation untuk memperoleh total hasil evaluasi $\sum \mathrm{WE}_{\mathrm{i}}=\mathrm{WE}_{1}+\mathrm{WE}_{2}+\mathrm{WE}_{3}+\mathrm{WE}_{\mathrm{n}}$

$\begin{array}{rlllllllll}\sum \mathrm{W}_{\text {Asus }} & = & 0,75+ & 0,4+ & 0,8+ & 0,8+ & 0,6+ & 0,2+ & 0,2 & =3,75 \\ \sum \mathrm{W}_{\text {Acer }} & = & 0,5+ & 0,3+ & 0,8+ & 0,4+ & 0,6+ & 0,15+ & 0,15 & =2,9 \\ \sum \mathrm{W}_{\text {Lenovo }} & = & 0,5+ & 0,2+ & 1+ & 0,8+ & 0,6+ & 0,15+ & 0,15 & =3,4 \\ \sum \mathrm{W}_{\text {Dell }} & = & 0,5+ & 0,2+ & 0,4+ & 0,6+ & 0,45+ & 0,15+ & 0,15 & =2,45 \\ \sum \mathrm{W}_{\text {Toshiba }} & = & 1+ & 0,3+ & 1+ & 0,8+ & 0,45+ & 0,2+ & 0,2 & =3,95\end{array}$

Berikut ini total hasil weight evaluation secara keseluruhan seperti yang ditunjukkan pada tabel berikut:

Tabel 17. Total Hasil Evaluasi

\begin{tabular}{llllllllll}
\hline No & PC & X1 & X2 & X3 & X4 & X5 & X6 & X7 & $\sum \mathrm{W}$ \\
\hline 1 & Asus & 0,75 & 0,4 & 0,8 & 0,8 & 0,6 & 0,2 & 0,2 & 3,75 \\
2 & Acer & 0,5 & 0,3 & 0,8 & 0,4 & 0,6 & 0,15 & 0,15 & 2,9 \\
3 & Lenovo & 0,5 & 0,2 & 1 & 0,8 & 0,6 & 0,15 & 0,15 & 3,4 \\
4 & Dell & 0,5 & 0,2 & 0,4 & 0,6 & 0,45 & 0,15 & 0,15 & 2,45 \\
5 & Toshiba & 1 & 0,3 & 1 & 0,8 & 0,45 & 0,2 & 0,2 & 3,95 \\
\hline
\end{tabular}

Berdasarkan tabel 17 dapat diperoleh $\sum \mathrm{W}$ tertinggi merupakan alternatif terbaik dalam pemilihan komputer gaming yakni alternatif Toshiba (A5) dengan $\sum \mathbf{W}=\mathbf{3 . 9 5}$ sebagai peringkat pertama dan alternatif Asus (A1) dengan $\sum \mathbf{W}=\mathbf{3 . 7 5}$ sebagai peringkat kedua.

\section{KESIMPULAN}

Kesimpulan yang didapat adalah Sistem Pendukung Keputusan dengan menggunakan metode Multi-Factor Evaluation Process (MFEP) pada pemilihan komputer gaming pada jasa penyedia warnet dapat dilakukan dengan menggunakan 7 kriteria: Prosesor (X1), Motherboard (X2), RAM (X3), VGA card (X4), Storage (X5), Casing (X6), Power Supply (X7) dan 5 alternatif: Asus (A1), Acer (A2), Lenovo (A3), Dell (A4) dan Toshiba (A5). Hasil dari penelitian menggunakan metode Multi-Factor Evaluation Process (MFEP) menunjukkan bahwa alternatif toshiba (A5) menjadi rekomendasi pertama dengan nilai akhir 3.95. Alternatif Asus (A1) menjadi rekomendasi kedua dengan nilai akhir 3.75 dan Lenovo (A3) menjadi rekomendasi ketiga dengan nilai akhir 3.4

\section{REFERENCES}

[1] Afrianty, I. \& Umbara, R., 2016. Sistem Pendukung Keputusan (SPK) Menentukan Kelayakan Calon Penerima Zakat Menerapkan Multi- Factor Evaluation Process (MFEP). Seminar Nasional Teknologi Informasi, Komunikasi dan Industri (SNTIKI) 8, (November), pp.87-94.

[2] Alhalimi, Z.. S., 2013. Sistem Pendukung Keputusan Pemilihan Lokasi Gudang Penyimpanan Pabrik Dengan Menggunakan Metode Brown-Gibson ( Studi Kasus : PT . Inti Kreasi ) Sistem Pendukung Keputusan Pemilihan Lokasi Gudang Penyimpanan Pabrik Dengan Menggunakan Metode Brown Gibson.

[3] Diana, 2016. Kelayakan Bisnis Menerapkan Simple Multi Attribute Rating Technique (SMART). Jurnal Ilmiah MATRIK, 18(2), pp.113-124.

[4] Hendini, A., 2016. Pemodelan UML sistem informasi Monitoring Penjualan dan stok barang. Jurnal khatulistia informatika, IV(2), pp.107-116.

[5] Novianti, D., Astuti, I.F. \& Khairina, D.M., 2016. Sistem Pendukung Keputusan Berbasis Web Untuk Pemilihan Café Menggunakan Metode Smart ( Simple Multi-Attribute Rating Technique ) (Studi Kasus : Kota Samarinda). In Seminar Sains dan Teknologi FMIPA Unmul. pp. 461-465.

[6] Primadasa, Yogi, and Veradilla Amalia. 2017. "Penerapan Metode Multi Factor Evaluation Process Untuk Pemilihan Tanaman Pangan Di Kabupaten Musi Rawas.” Jurnal Sisfo 7(1): 47-58. 


\section{TIN: Terapan Informatika Nusantara}

Vol 2, No 8, Januari 2022, Hal 513-520

ISSN 2722-7987 (Media Online)

Website https://ejurnal.seminar-id.com/index.php/tin

DOI 10.47065/tin.v2i8.1246

[7] Sesnika, N., Andreswari, D. \& Efendi, R., 2016. Aplikasi Sistem Pendukung Keputusan Pemilihan Gedung Serba Guna Di Kota Bengkulu Dengan Menggunakan Metode Smart Berbasis Android. Jurnal Rekursif, 4(1), pp.30-44.

[8] Yulianti, E., 2015. Sistem Pendukung Keputusanpemilihan Mobil Dengan Metoda Simple Multy Attribute Rating (SMART). Jurnal Momentum, 17(1), pp.55-59. 